\title{
コム用老化防止剤の略号 1119-1976 An Abbreviation of Rubber Antioxidants
}

1. 適用簕囲 この規格は, ゴムに用いられる老化防止剤の略号（以下略号という）について規定する.

2. 略号の形式 略号の形式は, 原則として化学成分名による英語表示の頭文字を組み合わせて表す.

3. 略 号 略号は, 表 1 による.

表 1

\begin{tabular}{|c|c|c|c|}
\hline 番号 & 系 & 略 号 & 化 学 成 分 名 \\
\hline \begin{tabular}{l|}
1 \\
2 \\
3 \\
4 \\
5
\end{tabular} & $p$ ーフェニレンジアミン誘導体 & $\begin{array}{l}\text { DNPD } \\
\text { DPPD } \\
\text { DTPD } \\
\text { IPPD } \\
\text { OPPD }\end{array}$ & 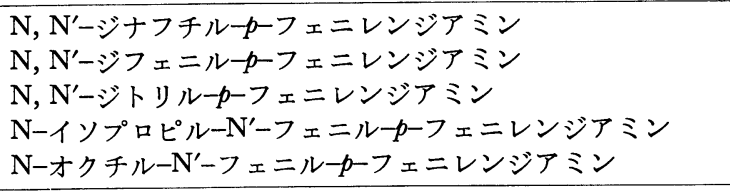 \\
\hline \begin{tabular}{r|}
6 \\
7 \\
8 \\
9 \\
10 \\
11 \\
12
\end{tabular} & ケトンーアミン縮合物 & $\begin{array}{l}\text { TMDQ } \\
\text { ETMDQ } \\
\text { MTMDQ } \\
\text { DTMDQ } \\
\text { ADPAL } \\
\text { ADPAR } \\
\text { APBN }\end{array}$ & 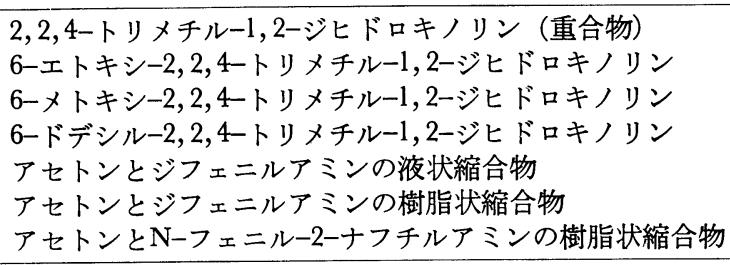 \\
\hline $\begin{array}{l}13 \\
14\end{array}$ & アルデヒドーアミン縮合物 & $\begin{array}{l}\text { AANR } \\
\text { AANP }\end{array}$ & $\begin{array}{l}\text { アルドールと1-ナフチルアミンの樹脂状縮合物 } \\
\text { アルドールと1-ナフチルアミンの粉末状縮合物 }\end{array}$ \\
\hline $\begin{array}{l}15 \\
16\end{array}$ & ナフチルアミン類 & $\begin{array}{l}\text { PAN } \\
\text { PBN }\end{array}$ & $\begin{array}{l}\mathrm{N}-フ ェ \text { ニル-1-ナフチルアミン } \\
\mathrm{N}-フ ェ \text { ニル-2-ナフチルアミン }\end{array}$ \\
\hline $\begin{array}{l}17 \\
18\end{array}$ & ジフェニルアミン誘導体 & $\begin{array}{l}\text { ODPA } \\
\text { TDPA }\end{array}$ & $\begin{array}{l}\text { オクチル化ジフェニルアミン } \\
\text { チカジフェニルアミン }\end{array}$ \\
\hline $\begin{array}{l}19 \\
20 \\
21 \\
22 \\
23\end{array}$ & モノフェノール類 & $\begin{array}{l}\text { MIPP } \\
\text { DTBMP } \\
\text { DTBMOP } \\
\text { DMTBP } \\
\text { SP }\end{array}$ & 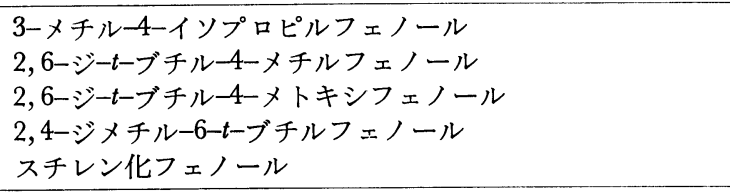 \\
\hline $\begin{array}{l}24 \\
25 \\
26\end{array}$ & ポリフェノール類 & $\begin{array}{l}\text { DBHQ } \\
\text { DAHQ } \\
\text { DMOB }\end{array}$ & 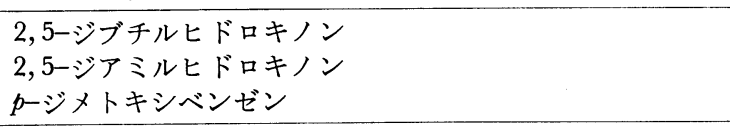 \\
\hline \begin{tabular}{l|}
27 \\
28 \\
29 \\
30
\end{tabular} & ビスフェノール類 & $\begin{array}{l}\text { BHOPC } \\
\text { MBMTB } \\
\text { BBMTBP } \\
\text { TBMTBP }\end{array}$ & 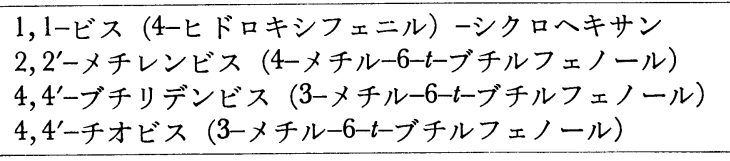 \\
\hline $\begin{array}{l}31 \\
32\end{array}$ & 有機チ才酸塩類 & $\begin{array}{l}\text { NiDBC } \\
\text { NiPX }\end{array}$ & $\begin{array}{l}\text { ジブチルジチオカルバミン酸ニッケル } \\
\text { イソプロピルキサントゲン酸ニッケル }\end{array}$ \\
\hline $\begin{array}{l}33 \\
34 \\
35\end{array}$ & エステル類 & $\begin{array}{l}\text { DLTDP } \\
\text { DSTDP } \\
\text { TNPP }\end{array}$ & $\begin{array}{l}\text { チオジプロピオン酸ジラウリル } \\
\text { チオジプロピオン酸ジステアリル } \\
\text { 亜リン酸トリ（ノニルフェニル） }\end{array}$ \\
\hline $\begin{array}{l}36 \\
37\end{array}$ & イミダゾール類 & $\begin{array}{l}\text { MBI } \\
\mathrm{ZnMBI}\end{array}$ & $\begin{array}{l}\text { 2-メルカプトベンズイミダゾール } \\
\text { 2-メルカプトベンズイミダゾールの亜鉛塩 }\end{array}$ \\
\hline
\end{tabular}

